\title{
Research on the Thermophysical Properties of Wall Materials of Dai nationality Dwelling
}

\author{
Liping $\mathrm{Li}^{1 \mathrm{a}}$,Shuai Fan ${ }^{2 \mathrm{a}}$ \\ ${ }^{1}$ Department of Architecture, Faculty of Architecture and Urban Planning, Kunming University of \\ Science and Technology, Kunming , Yunnan Province, China \\ ${ }^{2}$ Yunnan Building Technology Development Center, Kunming, Yunnan Province, China \\ fs1204@sina.com
}

Keywords: Dai nationality dwelling; wall materials; thermophysical properties; test and analysis Abstract. In this paper, taking the Dai-nationality dwellings of different materials in JingHong in Xishuaibanna as a research object, field tests for the thermophysical properties of wall materials in the sunmmer were carried out, that have tested the temperature of wall-surface and indoor temperature, and contrast to analysis tested parameters. The results of the test show wall material thermophysical characteristics in Xishuaibanna and variations of temperature effecting indoor thermal comfortable. The proposes and measures be taken out from this test for improving the thermophysical properties of wall materials and the comfortable of the indoor thermal environment.

\section{Introduction}

Jinghong in Xishuaibanna, with an elevation of 530m, belongs to the cold climate region (IV) according to the Standard of Climatic Regionalization for Architecture (GB50178 - 93) [1] and Thermal Design Code for Civil Building (GB 50176-93) [2]. The average temperature ranges from $18^{\circ} \mathrm{C}$ to $21.8^{\circ} \mathrm{C}$, the air temperature of 38 degrees in summer . This area features particularly hot and wet, as shown in Fig.1.

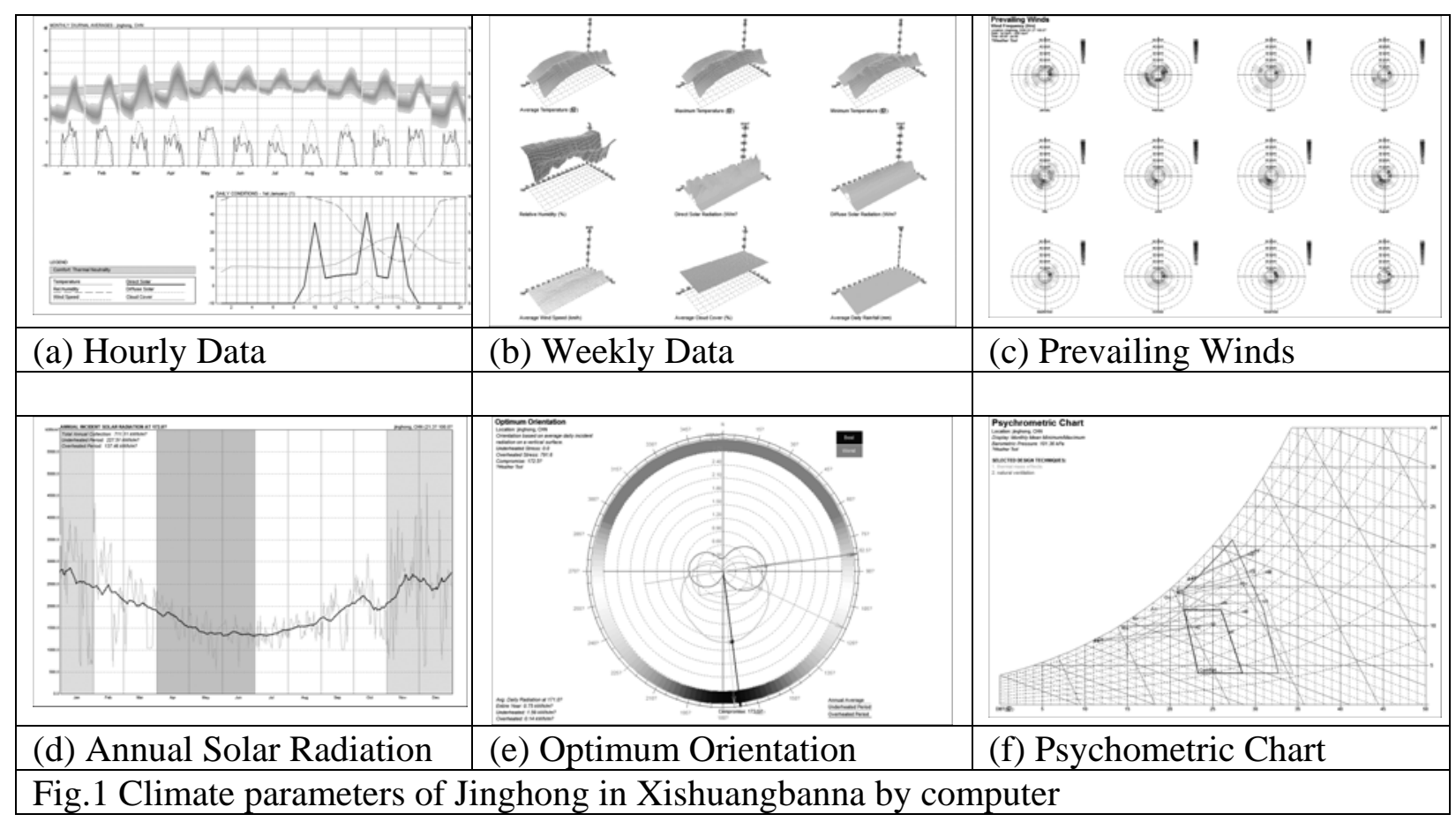




\section{Test Purpose and Basic Information on Buildings}

In order to understand the current situations of indoor thermal environment of Dai nationality dwellings of different materials in Jinghong of Xishuangbanna, we tested on such parameters as indoor temperature of Dai nationality dwellings with wood walls and brick walls, and the surface temperature of building envelope in summer, and found out the changes rules and features of the test parameters through comparative analysis, which provides a necessary actual measurement basis for improving the comfort of indoor thermal environment of Dai-style dwellings in summer.
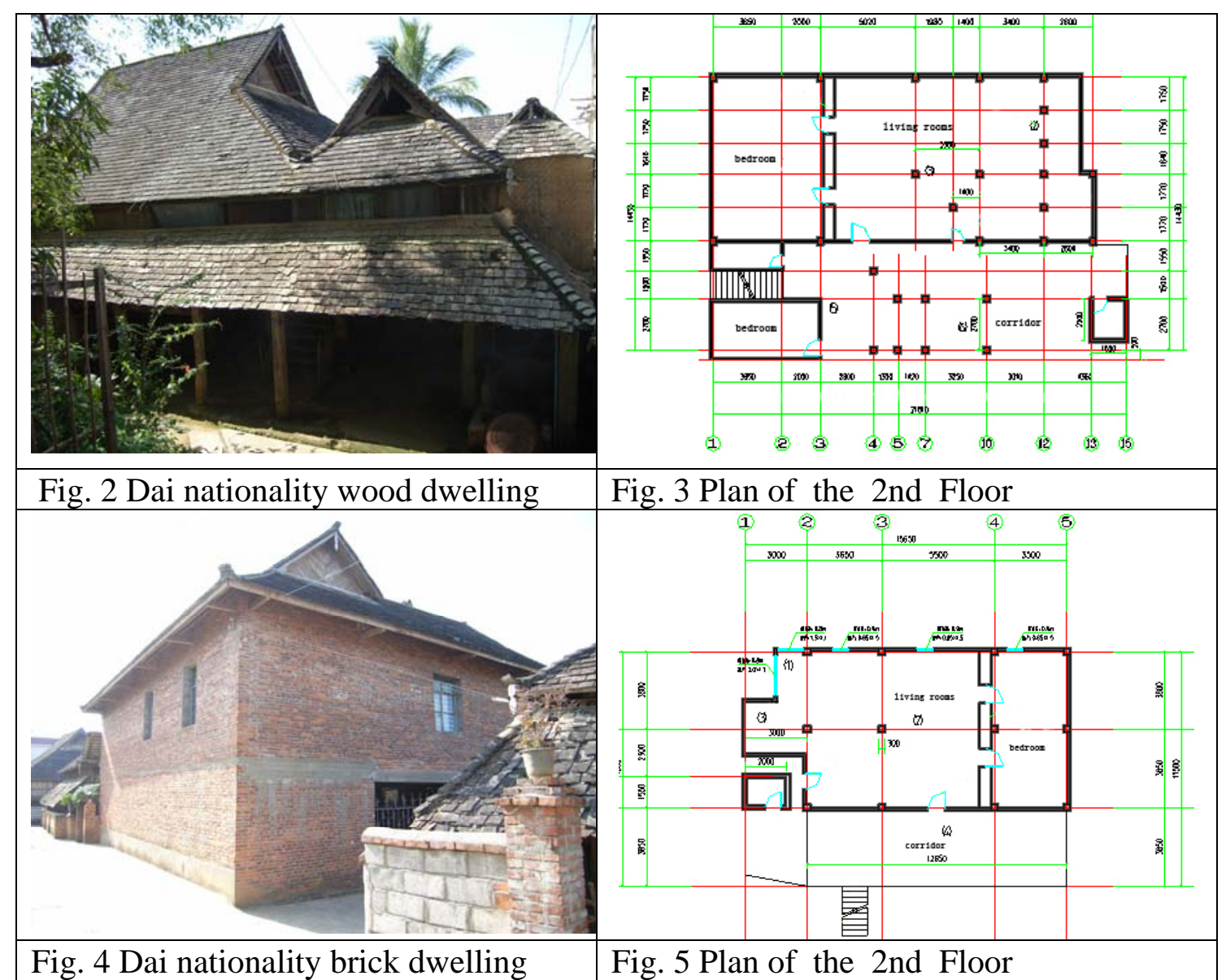

We carried out tests on several typical dwellings in Xishuangbanna, to research and compare the thermal insulation properties of traditional several typical walls. In the buildings tested, one is a traditional wood dwelling in the south-north orientation, which is of square shape in plane and has three rooms; and the other is a dwelling of brick and concrete structure in the south-north direction, which is of rectangular shape in plane with three rooms. dwelling is a traditional Dai nationality dwelling in the south-north orientation, which is of square shape in plane and has several rooms. The traditional wood dwelling is as shown in Fig.2,- Fig.5. The walls of this dwelling are wood walls and brick walls, and a wall nearby a corridor. The pillars has support the floor in 1st floor, and no wall around, which is beneficial for natural ventilation and reduces the heat in summer. The 2nd floor is main space where the Dai nationality lives, which is of square shape in plane with a living room and bedrooms. The corridor on the 2nd floor is also open. The roof is Jehiel mountain type clay tile roofs.

\section{Test Methods, Test Instruments and Layout of Testing Points}

The tests were carried out continuously for 48h during May 4th-6th, which started from 07:48 till 06:48 of the day after tomorrow, with an interval of $1 \mathrm{~h}$. To reduce the measurement error, all test instruments had been calibrated prior to the test. The tests were carried out in summer, during which this area featured cold night and strong solar radiation in the daytime outdoors, and it had a highest 
outdoor temperature of $38^{\circ} \mathrm{C}$ and a lowest temperature of $21^{\circ} \mathrm{C}$ at the place with a high of $1.5 \mathrm{~m}$. Thus this day may represent the typical outdoor climate of Xishuangbanna in summer.

Raytek RayngerST infrared thermometer manufactured by America was used for measuring the temperature, with the measurement ranging from $-32^{\circ} \mathrm{C}$ to $535^{\circ} \mathrm{C}$ and a precision of $0.1^{\circ} \mathrm{C}$, which may be used for measuring the surface temperature of the ground, wall and roof. Moreover, UNITEC MCT-111 portable digital thermometer manufactured by Unite Technique Development Company was adopted for measuring the indoor and outdoor air temperature, with the measurement ranging from $-200^{\circ} \mathrm{C}$ to $400^{\circ} \mathrm{C}$ and a precision of $0.1^{\circ} \mathrm{C}$, which has 0.1 resolution within the scope of $-200^{\circ} \mathrm{C}--200^{\circ} \mathrm{C}$.

Layout of testing points: according to the situations of Tibetan-style dwellings, the testing points were arranged at the middle of the rooms about $1.5 \mathrm{~m}$ above the ground to measure the air temperature; and at the middle of the surface of building envelopes of different materials for measuring the surface temperature .

\section{Test Results and Research Analysis}

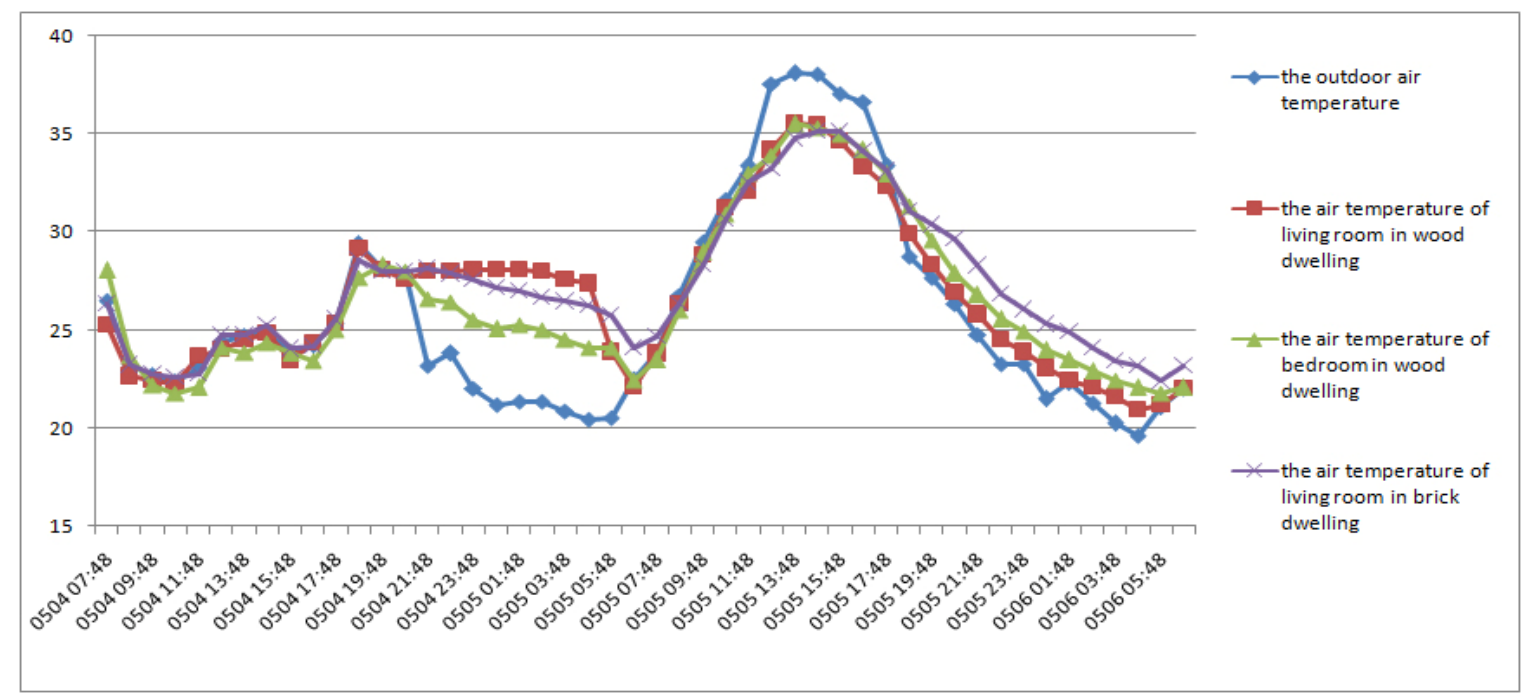

Fig.6 Comparison on air temperature of rooms in Dai nationality dwellings

Table 1.Comparison of the air temperature of the rooms with the outdoor air temperature

\begin{tabular}{|l|l|l|l|l|l|l|}
\hline & \multicolumn{2}{|l|}{$\begin{array}{l}\text { Maximum } \\
\text { temperature }\left[{ }^{\circ} \mathrm{C}\right]\end{array}$} & \multicolumn{2}{l|}{$\begin{array}{l}\text { Minimum } \\
\text { temperature }\left[{ }^{\circ} \mathrm{C}\right]\end{array}$} & \multicolumn{2}{l|}{$\begin{array}{l}\text { Average } \\
\text { temperature }\left[{ }^{\circ} \mathrm{C}\right]\end{array}$} \\
\hline the outdoor air temperature & \multicolumn{2}{|l|}{38.1} & \multicolumn{2}{l|}{19.6} & \multicolumn{2}{l|}{25.8} \\
\hline $\begin{array}{l}\text { Air temperature of bedroom } \\
\text { in wood dwelling }\end{array}$ & 35.5 & 2.6 lower & 21.7 & 2.1 higher & 26.4 & 0.6 higher \\
\hline $\begin{array}{l}\text { Air temperature of living } \\
\text { room in wood dwelling }\end{array}$ & 35.6 & 2.5 lower & 20.9 & 1.3 higher & 26.6 & 0.8 higher \\
\hline $\begin{array}{l}\text { Air temperature of living } \\
\text { room in brick dwelling }\end{array}$ & 35.2 & 2.9 lower & 22.4 & 2.8 higher & 27.2 & 1.4 higher \\
\hline
\end{tabular}

As shown in Fig.6 and Table 1,in the rooms of Dai nationality wood dwelling on the 2nd floor ,the outdoor temperature reached the peak of $38.1^{\circ} \mathrm{C}$ at $13: 48$ p.m., while the air temperature of the living room , bedroom in wood dwelling and the living room in brick dwelling ,arrived at the maximum of $35.6^{\circ} \mathrm{C}, 35.5^{\circ} \mathrm{C}$ at $13: 48 \mathrm{p} . \mathrm{m}$ and $35.2^{\circ} \mathrm{Cat} 14: 48 \mathrm{p} . \mathrm{m}$. The maximum air temperature of the living room, bedroom in wood dwelling and the living room in brick dwelling is $2.5^{\circ} \mathrm{C}, 2.6^{\circ} \mathrm{C}, 2.9^{\circ} \mathrm{C}$ lower than the outdoor air temperature. The maximum air temperature of the living room in wood dwelling 
is $0.4^{\circ} \mathrm{Chigher}$ than one of brick dwelling. The minimum outdoor temperature was $19.6^{\circ} \mathrm{C}, 1.3^{\circ} \mathrm{C}$ higher than the minimum air temperature of the living room in wood dwelling which was $20.9^{\circ} \mathrm{C}$, $2.1^{\circ} \mathrm{C}$ higher than the minimum air temperature of the bedroom which was $21.7^{\circ} \mathrm{C}, 2.8^{\circ} \mathrm{C}$ higher than the minimum air temperature of the living room in wood dwelling which was $22.4^{\circ} \mathrm{C}$. The minimum air temperature of the living room in wood dwelling is $0.5^{\circ}$ Chigher than one of brick dwelling. The average outdoor temperature was $25.8^{\circ} \mathrm{C}, 0.8^{\circ} \mathrm{C}$ higher than the average air temperature of the living room of $26.6^{\circ} \mathrm{C}$, and $0.6^{\circ} \mathrm{C}$ higher than the average air temperature of the bedroom of $26.4^{\circ} \mathrm{C}$.

Table 2.Comparison on the amplitude of the air temperature

\begin{tabular}{|l|l|l|l|}
\hline \multirow{2}{*}{} & \multicolumn{2}{|l|}{ fluctuation $\left[{ }^{\circ} \mathrm{C}\right]$} & amplitude $\left[{ }^{\circ} \mathrm{C}\right]$ \\
\cline { 2 - 4 } & & & \\
\hline the outdoor temperature & 38.1 & 19.6 & 18.5 \\
\hline $\begin{array}{l}\text { the air temperature of the bedroom in wood } \\
\text { dwelling }\end{array}$ & 35.5 & 21.7 & 13.8 \\
\hline $\begin{array}{l}\text { the air temperature of the living room in wood } \\
\text { dwelling }\end{array}$ & 35.6 & 20.9 & 14.7 \\
\hline $\begin{array}{l}\text { the air temperature of the living room in brick } \\
\text { dwelling }\end{array}$ & 35.2 & 22.4 & 12.8 \\
\hline
\end{tabular}

As is shown in the Table 2 the outdoor air temperature fluctuated from $19.6^{\circ} \mathrm{C}$ to $38.1^{\circ} \mathrm{Cin}$ summer, with an amplitude of $18.5^{\circ} \mathrm{C}$, and the minimum and maximum temperature occurred respectively at 4:48 on May 6 and 13:48 on May 5. In the living room of Dai nationality wood dwelling, the indoor air temperature fluctuated from $20.9^{\circ} \mathrm{C}$ to $35.6^{\circ} \mathrm{C}$, with amplitude of $14.7^{\circ} \mathrm{C}$, and the minimum and maximum temperature occurred respectively at 4:48 on May 6 and 13:48 on May 5 . The amplitude is $1.9^{\circ}$ Chigher than one of brick dwelling. In the bedroom of Dai nationality wood dwelling, the indoor air temperature fluctuated from $21.7^{\circ} \mathrm{C}$ to $35.5^{\circ} \mathrm{C}$, with amplitude of $13.8^{\circ} \mathrm{C}$, and the minimum and maximum temperature occurred respectively at 5:48 on May 6 and 13:48 on May 5. The amplitude of indoor air temperature is similar that of outdoor air temperature.

\section{Conclusion}

It can be concluded from the comparison of air temperature of corridors and rooms of Dai nationality wood dwelling:

(1) The maximum air temperature of the living room in Dai nationality wood dwelling is $0.4^{\circ}$ Chigher than one of brick dwelling; the minimum air temperature is $0.5^{\circ} \mathrm{C}$ higher than one of brick dwelling; and the average air temperature is $0.6^{\circ} \mathrm{C}$ higher than one of brick dwelling.

(2) The indoor air temperature in wood dwelling fluctuated from $20.9^{\circ} \mathrm{C}$ to $35.6^{\circ} \mathrm{C}$, with amplitude of $14.7^{\circ} \mathrm{C}$, and the minimum and maximum temperature occurred respectively at 4:48 on May 6 and 13:48 on May 5.

(3) The indoor air temperature in brick dwelling fluctuated from $22.4^{\circ} \mathrm{C}$ to $35.2^{\circ} \mathrm{C}$, with amplitude of $12.8^{\circ} \mathrm{C}$, and the minimum and maximum temperature occurred respectively at 4:48 on May 6 and 14:48 on May 5.

(4)The test results also show that pillars has support the floor in 1st floor, and no wall around, which is beneficial for natural ventilation and reduces the heat in summer.

\section{References}

[1].Standard of Climatic Regionalization for Architecture (GB50178-93), in Chinese.

[2].Thermal Design Code for Civil Building (GB 50176-93),in Chinese. 